Provided for non-commercial research and education use. Not for reproduction, distribution or commercial use.

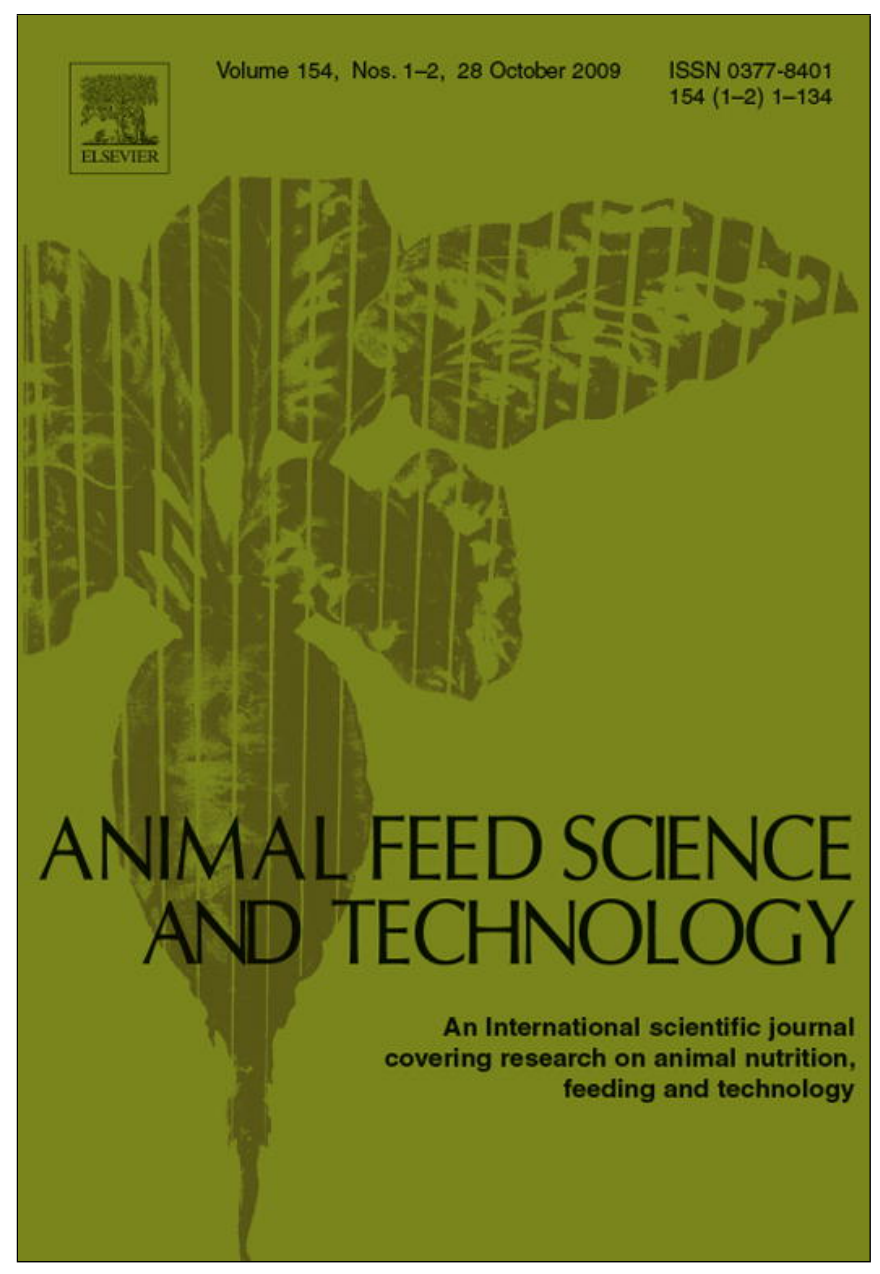

This article appeared in a journal published by Elsevier. The attached copy is furnished to the author for internal non-commercial research and education use, including for instruction at the authors institution and sharing with colleagues.

Other uses, including reproduction and distribution, or selling or licensing copies, or posting to personal, institutional or third party websites are prohibited.

In most cases authors are permitted to post their version of the article (e.g. in Word or Tex form) to their personal website or institutional repository. Authors requiring further information regarding Elsevier's archiving and manuscript policies are encouraged to visit:

http://www.elsevier.com/copyright 


\title{
Influence of exogenous enzymes on nutrient digestibility, extent of ruminal fermentation as well as milk production and composition in dairy cows
}

\author{
H.M. Gado ${ }^{\text {a }}$, A.Z.M. Salem ${ }^{\text {b,e, }, * 1}$, P.H. Robinson ${ }^{c}$, M. Hassan $^{\mathrm{d}}$ \\ a Department of Animal Productions, Faculty of Agriculture, Ain Shams University, Cairo, Egypt \\ b Department of Animal Production, Faculty of Agriculture (El-Shatby), Alexandria University, Alexandria, Egypt \\ c Department of Animal Science, University of California, Davis, CA 95616-8521, USA \\ ${ }^{d}$ Department of Animal Productions, Faculty of Agriculture, Cairo University, Cairo, Egypt \\ e Centro Universitario UAEM-Temascaltepec, Universidad Autónoma del Estado de México, Mexico
}

\section{A R T I C L E I N F O}

\section{Article history:}

Received 22 October 2008

Received in revised form 22 May 2009

Accepted 23 July 2009

\section{Keywords:}

$\mathrm{ZADO}^{\circledR}$

Enzymes

Digestibility

SCFA

Rumen microbial protein

Milk production

\begin{abstract}
A B S T R A C T
This experiment studied effects of a mixture of exogenous enzymes $\left(Z A^{\circledR}{ }^{\circledR}\right)$ from anaerobic bacteria on ruminal fermentation, feed intake, digestibility, as well as milk production and composition in cows fed total mixed rations (TMRs; 0.7 corn silage and 0.3 of a concentrate mixture). Twenty lactating multiparous Brown Swiss cows ( $500 \pm 12.4 \mathrm{~kg}$ live weight) were randomly assigned into two experimental groups of 10 immediately after calving and fed a TMR with or without (CTRL) addition of $40 \mathrm{~g} / \mathrm{cow} / \mathrm{d}$ of enzymes for 12 weeks. Addition of enzymes increased $(P<0.05)$ rumen microbial $\mathrm{N}$ synthesis. Intake of dry matter (DM) and organic matter $(\mathrm{OM})$ was positively influenced $(P<0.05)$ by supplementation, and digestibility of all nutrients was higher $(P<0.05)$ in the total tract of supplemented cows, although the magnitude of the improvement varied among nutrients, with the highest improvement in aNDFom and ADFom (418-584 and 401-532 $\mathrm{g} / \mathrm{kg}$ respectively;
\end{abstract}

Abbreviations: ADFom, acid detergent fiber; CTRL, control diet; CP, crude protein; DM, dry matter; aNDFom, neutral detergent fiber; OM, organic matter; TMR, total mixed ration.

* Corresponding author. Current address: Centro Universitario UAEM-Temascaltepec, Universidad Autónoma del Estado de México, México. Tel.: +01(521) 7162695171; fax: +01(521) 7162695171.

E-mail address: asalem70@yahoo.com (A.Z.M. Salem).

1 Department of Animal Production, Faculty of Agriculture (El-Shatby), Alexandria University, Egypt. Tel.: +20 3 5292727; fax: +20 35922780 . 
$P<0.05)$ than the other nutrients. Supplementation of enzymes also increased $(P<0.05)$ rumen ammonia $\mathrm{N}$ and total short chain fatty acid (SCFA) concentrations, and individual SCFA proportions were also altered with an increase in acetate $(61.0-64.8 \mathrm{~mol} / 100 \mathrm{~mol}$; $P=0.05$ ) before feeding, and acetate and propionate increased $3 \mathrm{~h}$ post-feeding $(60.0-64.0$ and $18.3-20.8 \mathrm{~mol} / 100 \mathrm{~mol}$ respectively; $P<0.05)$. Milk and milk protein production was higher $(12.8-15.7$ and $0.45-0.57 \mathrm{~kg} / \mathrm{d}$ respectively; $P<0.05)$ for cows fed the $\mathrm{ZADO}^{\circledR}$ supplemented diet. This exogenous enzyme product, supplemented daily to the TMR of cows in early lactation, increased milk production due to positive effects on nutrient intake and digestibility, extent of ruminal fermentation and microbial protein synthesis.

(c) 2009 Elsevier B.V. All rights reserved.

\section{Introduction}

Recent research has demonstrated that supplementing diets of dairy cows and feedlot cattle with fiber degrading enzymes can improve feed utilization and animal performance by enhancing fiber degradation in vitro (Hristov et al., 1996; Gado et al., 2007; El-Adawy et al., 2008; Rodrigues et al., 2008), in situ (Feng et al., 1996; Lewis et al., 1996; Tricarico et al., 2005; Krueger et al., 2008), and in vivo (Yang et al., 1999; Gado et al., 2007; Salem et al., 2007; Gado and Salem, 2008). Feeding enzymes is often accompanied by increased feed intake, which may partly be due to increased palatability of the diet due to sugars released by pre-ingestive fiber hydrolysis. However post-ingestive enzyme effects, such as increased digestion rate and/or extent of digestion (Beauchemin and Rode, 1996; Feng et al., 1996; Gado and Salem, 2008; Krueger et al., 2008) may increase hydrolytic activity in the rumen to reduce gut fill and enhance feed intake (Adesogan, 2005).

Proposed modes of action of direct-fed enzymes include solubilization of dietary fiber before ingestion, provision of readily fermentable substrate for ruminal microorganisms and/or enhancement of microbial enzyme activity in the rumen (McAllister et al., 2001). A variety of factors, such as the specific activity of the enzymes, their mode and level of application, as well as the type of animal and its diet, may affect enzyme efficacy. Direct-fed enzymes can also enhance microbial colonization of feed by increasing numbers of ruminal fibrolytic microbes (Morgavi et al., 2000; Nsereko et al., 2000) to increase rate of degradation of fiber in the rumen (Yang et al., 1999; Tricarico et al., 2005; Giraldo et al., 2008), rumen microbial protein synthesis (Yang et al., 1999; Nsereko et al., 2002) and forestomach digestibility.

Positive effects of adding exogenous enzymes to ruminant diets have been reported for lactating dairy cows and growing cattle. Dairy cows fed forage treated with a fibrolytic enzyme additive ate more feed and produced 5-25\% more milk (Lewis et al., 1995; Tricarico et al., 2005; Stella et al., 2007), improved the energy balance of transition dairy cows (DeFrain et al., 2005) and increased milk production in small ruminants (Titi and Lubbadeh, 2004; Stella et al., 2007). In feedlot cattle, fibrolytic enzymes have improved live weight (LW) gain by as much as $35 \%$ and feed conversion ratio by up to 10\% (Beauchemin et al., 1995).

A commercial exogenous enzyme mixture $\left(\mathrm{ZADO}^{\circledR}\right)$, prepared from anaerobic bacterium, has been shown to improve ruminal fermentation, $\mathrm{N}$ balance and nutrient digestibility, as well as milk yield of cows fed diets containing Egyptian by-product feeds (Gado et al., 2007; Soliman, 2006), as well as LW gain and feed conversion of wheat straw in sheep and goats (Gado and Salem, 2008; Salem et al., 2007). Our objective was to evaluate impacts of $Z A D O^{\circledR}$ supplemented to a total mixed ration (TMR) of dairy cows on feed intake and digestibility, ruminal fermentation and microbial protein synthesis, as well as on milk production and composition. 
pling feces from the rectum of each cow at five equally spaced times per day on week 12 of the study. Fecal samples, for determination of digestibility, were composited by cow, dried at $55^{\circ} \mathrm{C}$, ground to pass a $1 \mathrm{~mm}$ screen and retained for chemical analyses.

On the 12th week of the study, samples of rumen fluid were withdrawn from each cow by stomach tube before the morning feeding (i.e., $0 \mathrm{~h}$ ) and $3 \mathrm{~h}$ after feeding on one day. Samples ( $50 \mathrm{ml} / \mathrm{cow}$ ) were immediately filtered and stored for short chain fatty acids (SCFAs; i.e., acetic, propionic, butyric acids) and ammonia $\mathrm{N}$ analysis. To determine microbial $\mathrm{N}$ synthesis, urine from each cow was collected for a period of $24 \mathrm{~h}$ and diluted to a fixed volume with water, and one sub-sample was stored at $-20^{\circ}$ for later analysis of purine derivatives.

Cows were milked in their tie-stalls at 0700 and $1700 \mathrm{~h}$, and milk yield was recorded daily and sampled on two days in weeks 11 and 12 of the study. Milk samples were preserved with potassium dichromate, stored at $4{ }^{\circ} \mathrm{C}$, and sent to the laboratory for compositional analysis.

\subsection{Sample analysis}

Amounts of TMR offered and refused were recorded daily by cow. Feed refusals from individual cows were collected, mixed within treatment and a representative sample frozen daily. Twice weekly composite samples of feed refusals were analyzed for DM, and the DM content of feed ingredients was determined weekly to adjust dietary formulations (if necessary) to account for small changes in ingredient DM contents. To determine DM, feed samples were dried at $60^{\circ} \mathrm{C}$ for $48 \mathrm{~h}$ in a forced air oven.

Dried samples were ground through a Wiley mill (Arthur H. Thomas, Philadelphia, PA, USA) using a $1 \mathrm{~mm}$ screen. Analytical DM content of the samples (feed, orts, feces) was determined by drying at $135^{\circ} \mathrm{C}$ for $3 \mathrm{~h}$, and organic matter (OM) was determined as the weight loss on ashing at $550^{\circ} \mathrm{C}$. Neutral detergent fiber (aNDFom) and acid detergent fiber (ADFom) were determined using the procedures of Van Soest et al. (1991). Sodium sulfite was not used in the procedure for aNDFom determination, but pre-treatment with heat stable amylase (type XI-A from Bacillus subtilis; Sigma, Sharkia, Egypt) was included. Both aNDFom and ADFom are expressed without residual ash.

Chromium, as a marker to calculate nutrient digestibility, was determined in fecal samples by atomic absorption spectrophotometry according to AOAC (2000; ID 952.02). Collected feed, refusals and fecal samples were analyzed for N, aNDFom and ADFom. A Kjeldahl method (AOAC, 1990; ID 954.01) was used to determine $\mathrm{N}$.

Ruminal pH was determined before rumen liquor was stored with a digital pH meter. Acetic, propionic and butyric acids in rumen fluid were quantified using crotonic acid as the internal standard using gas chromatography (model 5890, Hewlett Packard, Little Falls, DE, USA) with a capillary column ( $30 \mathrm{~m} \times 0.25 \mathrm{~mm}$ i.d., $1 \mathrm{~m}$ phase thickness, Supelco Nukol; Sigma-Aldrich, Mississauga, ON, Canada), and flame ionization detection. Oven temperature was $100^{\circ} \mathrm{C}$ for $1 \mathrm{~min}$, which was then ramped by $20^{\circ} \mathrm{C} / \mathrm{min}$ to $140^{\circ} \mathrm{C}$, and then by $8-200^{\circ} \mathrm{C} / \mathrm{min}$, and held at this temperature for $5 \mathrm{~min}$. The injector temperature was $200^{\circ} \mathrm{C}$, the detector temperature was $250^{\circ} \mathrm{C}$, and the carrier gas was He. Concentrations of $\mathrm{NH}_{3}-\mathrm{N}$ were determined using the colorimetric method described by Rhine et al. (1998). A standard curve was made to determine whether a linear relationship existed between varying concentrations of ammonium sulfate standard solution and intensity of color produced by Nesslerization. Ten test tubes containing $0.10-1.0 \mathrm{ml}$ of standard solution were prepared. To each test tube, $0.04 \mathrm{ml}$ of Nessler's reagent was added and volume was made up to $5 \mathrm{ml}$ with distilled water. The intensity of color thus developed was measured at a wavelength of $420 \mathrm{~nm}$ on Spectronic 21 within 5-10 min after setting it at 0 absorbance with the blank.

Sub-samples of urine were analyzed for allantoin by high-performance liquid chromatography with pre-column derivation according to Chen et al. (1993) and for uric and hypoxanthine plus xanthine according to Chen et al. (1990). In the latter method, hypoxanthine and xanthine were determined collectively as uric acid after treatment with xanthine oxidase. Urine samples were diluted with distilled water before the assays, by 40 times for allantoin and 10 times for uric and hypoxanthine plus xanthine. The N content of urine was determined by the method of Davidson et al. (1970). All daily urine samples were analyzed individually. Rumen microbial $\mathrm{N}$ was calculated depending on the total purine derivatives (i.e., allantoin and uric acid measured) according to Chen et al. (1990). 
Daily milk weights were recorded during weeks 11 and 12 of the experiment. Milk samples were analyzed for fat, crude protein (CP) and lactose with Milk-O-Scan 605 (Foss Electric, Hillerod, Denmark) based on infrared technology. Final milk composition for each week was expressed as the weighted yield of the two daily milkings. Average fat and $\mathrm{CP}$ yields were calculated by multiplying milk yield by fat and $\mathrm{CP}$ content of milk on an individual cow basis. Milk energy ( $\mathrm{MJ} / \mathrm{kg}$ ) was calculated on an individual cow basis using the milk fat, CP and lactose content of the milk (Tyrrell and Reid, 1965).

\subsection{Statistical analysis}

Statistical analysis was completed on data from weeks 11 and 12 of the experiment, considering the period from weeks 1 to 10 to be an adaptation period. Collected data on nutrient intake and digestibility, ruminal fermentation parameters and milk yield and composition in the two cows groups (i.e., CTRL and ZADO ${ }^{\circledR}$ enzymes) were analyzed as a factorial design using the general linear models procedure of SAS (2001), with methods of Steel and Torrie (1980) to determine differences due to enzymes addition. The significance level of the test was $P<0.05$.

\section{Results}

Intake of DM and OM was positively influenced by enzyme supplementation (Table 2), but aNDFom intake was not. Digestibility of DM, OM, aNDFom and ADFom was higher $(P<0.05)$ in the total tract of $\mathrm{ZADO}^{\circledR}$ enzyme supplemented cows by $8-16 \%$.

Enzyme supplemented cows had higher $(P<0.05)$ SCFA and ammonia N concentrations (Table 3 ) pre-feeding (122 versus $111 \mathrm{mmol} / 100 \mathrm{ml} ; 126$ versus $110 \mathrm{mg} / \mathrm{l}$ respectively) and at $3 \mathrm{~h}$ post-feeding (128 versus $119 \mathrm{mmol} / 100 \mathrm{ml} ; 67$ versus $55 \mathrm{mg} / \mathrm{l}$ respectively). Acetate was increased before feeding, and acetate and propionate $3 \mathrm{~h}$ post-feeding, with enzyme supplementation. There was an increase in $\mathrm{N}$ in the ZADO group. There were also an increase in excretion of $\mathrm{N}$ in urine and feces in the ZADO group, but this was not statistically significant. The $\mathrm{N}$ balance in the ZADO group was higher than in the control group. Microbial N synthesis was higher in enzyme supplemented cows (220 versus $190 \mathrm{~g} / \mathrm{d}$; $P<0.05)$.

Output of milk and milk energy was higher $(P<0.05)$ for cows fed the enzyme supplemented diet (Table 4). However, increased milk yield for cows fed enzymes was not accompanied by increases in yield of milk components, except $\mathrm{CP}$, which was increased $(P<0.05)$ by addition of enzymes product.

\section{Table 2}

Intake, whole tract nutrients digestibility and nitrogen balance of the TMR ${ }^{\mathrm{a}}$ fed to dairy cows supplemented with $\left(\right.$ ZADO $\left.{ }^{\circledR}\right)$ or without (CTRL) the exogenous enzymes mixture.

\begin{tabular}{|c|c|c|c|c|}
\hline & CTRL & $\mathrm{ZADO}^{\circledR}$ & SEM & Significance $(P)$ \\
\hline \multicolumn{5}{|l|}{ Intake (kg/d) } \\
\hline DM & 16.1 & 18.2 & 0.21 & 0.049 \\
\hline $\mathrm{OM}$ & 14.1 & 16.4 & 0.14 & 0.048 \\
\hline aNDFom & 7.1 & 7.4 & 0.23 & 0.192 \\
\hline ADFom & 4.04 & 4.57 & 0.11 & 0.087 \\
\hline \multicolumn{5}{|l|}{ Digestibility (g/kg) } \\
\hline DM & 663 & 743 & 2.1 & 0.045 \\
\hline $\mathrm{OM}$ & 667 & 741 & 2.9 & 0.047 \\
\hline aNDFom & 418 & 584 & 2.8 & 0.049 \\
\hline ADFom & 401 & 532 & 2.3 & 0.046 \\
\hline \multicolumn{5}{|l|}{ Nitrogen balance } \\
\hline $\mathrm{N}$ intake (g/d) & 1654 & 1870 & 54 & 0.07 \\
\hline Urinary N (g/d) & 509 & 542 & 12.6 & 0.11 \\
\hline Fecal $N(\mathrm{~g} / \mathrm{d})$ & 659 & 711 & 14.3 & 0.17 \\
\hline N balance $(\mathrm{g} / \mathrm{d})$ & 486 & 617 & 11.9 & 0.06 \\
\hline
\end{tabular}

DM, dry matter; OM, organic matter; ADFom, acid detergent fiber; aNDFom, neutral detergent fiber.

a TMR: total mixed ration without $(\mathrm{CTRL})$ or with $\left(\mathrm{ZADO}^{\circledR}\right)$ the commercial exogenous enzyme mixture. 
Table 3

Ruminal pH, short chain fatty acids (SCFAs, total and individual), ammonia N concentrations (after 0 and $3 \mathrm{~h}$ of feeding); microbial nitrogen synthesis of the TMR ${ }^{\mathrm{a}}$ fed to dairy cows supplemented with $\left(\right.$ ZADO $^{\circledR}$ ) or without (CTRL) the exogenous enzymes mixture.

\begin{tabular}{|c|c|c|c|c|}
\hline & CTRL & $\mathrm{ZADO}^{\circledR}$ & SEM & Significance $(P)$ \\
\hline $\mathrm{pH}$ & 6.1 & 5.9 & 0.24 & 0.41 \\
\hline \multicolumn{5}{|l|}{ Before feeding $(0 \mathrm{~h})$} \\
\hline Total SCFA (mmol/l) & 111 & 122 & 2.1 & 0.34 \\
\hline \multicolumn{5}{|c|}{ Individual SCFA ( $\mathrm{mol} / 100 \mathrm{~mol})$} \\
\hline Acetate $(\mathrm{A})$ & 61.0 & 64.8 & 1.30 & 0.05 \\
\hline Propionate (P) & 17.8 & 18.1 & 0.83 & 0.13 \\
\hline Butyrate & 11.3 & 11.9 & 0.81 & 0.24 \\
\hline A:P ratio & 3.43 & 3.85 & 1.162 & 0.14 \\
\hline Ammonia N (mg/l) & 55 & 67 & 0.37 & 0.04 \\
\hline \multicolumn{5}{|l|}{ Post-feeding (3 h) } \\
\hline Total SCFA (mmol/l) & 119.2 & 128 & 3.6 & 0.04 \\
\hline \multicolumn{5}{|c|}{ Individual SCFA (mol/100 mol) } \\
\hline Acetate $(A)$ & 60.0 & 64.0 & 1.2 & 0.04 \\
\hline Propionate $(\mathrm{P})$ & 18.3 & 20.8 & 0.87 & 0.01 \\
\hline Butyrate & 10.9 & 11.0 & 0.96 & 0.31 \\
\hline A:P ratio & 3.28 & 3.08 & 0.070 & 0.01 \\
\hline Ammonia $\mathrm{N}(\mathrm{mg} / \mathrm{l})$ & 110 & 126 & 2.3 & 0.05 \\
\hline Microbial N (g/d) & 190 & 220 & 9.6 & 0.04 \\
\hline Uric acid (mmol/d) & 22.4 & 24.6 & 0.67 & 0.16 \\
\hline Allantoin $(\mathrm{mmol} / \mathrm{d})$ & 308 & 304 & 10.4 & 0.26 \\
\hline
\end{tabular}

a TMR: total mixed ration without (CTRL) or with $\left(\mathrm{ZADO}^{\circledR}\right)$ the commercial exogenous enzyme mixture.

\section{Discussion}

\subsection{Nutrient intake and digestibility}

Increased DM intake by addition of enzymes may be partly due to increased nutrient digestibility, which is consistent with previous results with the same enzyme mixture (Soliman, 2006; Gado et al., 2007; Salem et al., 2007; El-Adawy et al., 2008; Gado and Salem, 2008). However the magnitude of DM intake increase was much higher in the present study, although the increase is consistent with sheep and goats (Salem et al., 2007).

In the current study, DM intake and digestibility were improved by about 13 and $9 \%$ respectively with enzyme addition. Other reports have also shown increases in DM, particularly fiber, digestibility

Table 4

Milk production and composition of the TMR ${ }^{\mathrm{a}}$ fed to dairy cows supplemented with $\left(\mathrm{ZADO}^{\circledR}\right.$ ) or without (CTRL) the commercial exogenous enzymes mixture.

\begin{tabular}{lllll}
\hline & CTRL & ZADO $^{\circledR}$ & SEM & Significance $(P)$ \\
\hline Milk & & & & 0.85 \\
$\quad$ Production (kg/d) & 12.8 & 15.7 & 8.15 & 0.046 \\
$\quad$ Energy (MJ/d) & 58.2 & 70.7 & & 0.041 \\
Milk composition (g/kg) & & & 2.4 & 0.242 \\
$\quad$ Fat & 39 & 38 & 1.7 & 0.361 \\
Protein & 35 & 36 & 2.2 & 0.126 \\
Lactose & 45 & 45 & & 0.047 \\
Milk component yield (kg/d) & & & 0.041 & 0.141 \\
Fat & 0.50 & 0.60 & 0.022 & \\
$\quad$ Protein & 0.45 & 0.57 & 0.054 & \\
$\quad$ Lactose & 0.58 & 0.71 & & \\
\hline
\end{tabular}

a TMR: total mixed ration without (CTRL) or with $\left(\mathrm{ZADO}^{\circledR}\right)$ the commercial exogenous enzyme mixture. 
with fibrolytic enzyme addition (Gado and Salem, 2008; Hristov et al., 2008). Bowman et al. (2002), for example, reported a $25 \%$ increase in total tract aNDFom digestibility with a fibrolytic enzyme product, but it appeared that most of the impact was post-ruminal. Our results are consistent with Beauchemin et al. (2001), who reported that the average increase in DM intake due to enzyme supplementation was $1.6 \mathrm{~kg} / \mathrm{d}$ in dairy cows. In contrast, Schingoethe et al. (1999) treated forage with $0.7-1.5 \mathrm{l} / \mathrm{t}$ forage DM with concentrated cellulase and xylanase enzymes and reported that cows fed treated and untreated forage had similar DM intake.

Generally, digestion of aNDFom varies due to the chemical composition of the diet (Varga et al., 1998), the size of the indigestible aNDFom fraction, the digestion rate of potentially digestible aNDFom and rumen outflow rate (Firkins et al., 1998), as well as use of feed additives. Exogenous fibrolytic enzymes would be expected to increase fiber digestion by increasing the rate of ruminal digestion of the potentially digestible aNDFom fraction (Yang et al., 1999), but increases in fiber digestion may also be, in part, due to reduced digesta viscosity (Hristov et al., 2000), alterations in ruminal fermentation (Nsereko et al., 2002) and/or enhanced attachment and colonization to the plant cell wall by ruminal microorganisms (Nsereko et al., 2000; Wang et al., 2001) and/or by synergism with enzymes in rumen fluid (Morgavi et al., 2000). However, increased fiber digestion is unlikely the result of supplemental enzyme activity alone because the contribution of added exogenous enzymes to total ruminal activity is relatively small (Beauchemin et al., 2001). Morgavi et al. (2000) demonstrated synergism between exogenous enzymes and ruminal enzymes such that the net combined hydrolytic effect in the rumen was much greater than that estimated from individual enzyme activities. Wang et al. (2001) reported that enzyme supplementation increased numbers of non-fibrolytic and fibrolytic bacteria in a batch culture system with rumen fluid. Stimulation of rumen microbial numbers by the use of enzymes could result in higher microbial biomass, which would provide more total polysaccharidase activity to digest feedstuffs. Consistent with this hypothesis, Yang et al. (1999) reported that enzyme supplementation of dairy cow diets increased feed digestion in the rumen and flow of microbial protein from the rumen. The beneficial effects on animal performance are likely to be highest for ruminants in negative energy balance, such as cows in early lactation (Rode et al., 1999), which is consistent with results of our study.

Previous studies in our laboratory (i.e., Gado et al., 2007) showed that this ZADO enzyme product improved in vitro DM and aNDFom digestibility of wheat straw in the first $24 \mathrm{~h}$ of incubation, which is consistent with Feng et al. (1996) and Wang et al. (2004), who suggested that exogenous fibrolytic enzymes increase rate of DM digestion. Our exogenous enzyme, rich in xylanolytic, cellulase, $\alpha$-amylase and protease activity, had positive effects on digestion of aNDFom in TMR, consistent with Krause et al. (1998), who suggested that enzymes can improve nutrient degradation in highconcentrate diets. Perhaps the net effects of fibrolytic enzyme mixtures are not limited to the dietary component to which the enzymes are applied, which may explain why fibrolytic enzymes can be effective in improving digestibility of the non-fiber carbohydrates in addition to increasing digestibility of fiber when enzymes are added to the concentrate portion of a diet, or to high-concentrate diets (Beauchemin et al., 2003).

\subsection{Ruminal fermentation and microbial protein synthesis}

Total and individual SCFA, in particular acetate and propionate, in the cows fed the enzyme diet suggest that enzymes improved ruminal fiber fermentation. Several studies (Lewis et al., 1999; Wang et al., 2001) have demonstrated that treatment of feed with fibrolytic enzymes before feeding increased ruminal enzyme activities. Our enzyme product contained some materials, such as sugars, that are fermented by rumen microorganisms, which could have increased rumen SCFA concentrations (Wallace et al., 2001; Colombatto et al., 2003; Gado and Salem, 2008; Giraldo et al., 2008; Ranilla et al., 2008). However these levels were low, and unlikely to have had a substantive impact.

Previous studies have shown that treatment of diets with enzymes before feeding, or incubation with ruminal fluid, enhanced beneficial effects of enzymes on ruminal fermentation (Wang et al., 2001; Giraldo et al., 2004; Gado and Salem, 2008). As pointed out by Colombatto et al. (2003), some have suggested that this could be due to creation of a stable enzyme-feed complex (Kung et al., 2000), but others have indicated the possibility of alteration in the fiber structure, which 
would stimulate microbial colonization (Nsereko et al., 2000; Giraldo et al., 2008; Ranilla et al., 2008). Wang et al. (2001) suggested that changes in rumen fermentation patterns may reflect a shift in the species profile of colonizing bacteria in response to enzyme treatment of feed with exogenous enzymes. That feeding enzymes increased the proportion of acetate in the rumen fluid may suggest that methane production was also increased, since acetate production is associated with release of $\mathrm{H}^{+}$which can be used by methanogens to form methane (Stewart et al., 1997), which represents a loss of energy to the host. Increased propionate proportion with enzyme supplementation may suggest synergism between exogenous enzymes in feeds and lactic acid bacteria in the rumen.

Our results may be consistent with Beauchemin et al. (2003), who reported that supplementing the diet of feedlot cattle with lactic acid bacteria increased the proportion of propionate and, consequently, decreased the proportion of butyrate in rumen fluid compared with the control. Results suggest that our enzyme supplemented diet stimulated lactic acid-utilizing bacteria which also produce propionate. Similarly, Kim et al. (2000) reported increased rumen propionate concentrations in steers fed lactic acid-producing bacterium.

The lower acetic/propionic acid ratio is consistent with increases in fiber degradation for cows supplemented with enzymes, indicating that the added enzymes made the fermentation more gluconeogenic, and thereby improved the energetic efficiency of fermentation. This shift in SCFA proportions could increase precursor availability, and improve nutrient utilization, particularly for dairy cows in early lactation when nutrient intake lags nutrient demand (Eun et al., 2007), possibly due to fermentation of sugars released by cell wall hydrolysis by enzymes. This agrees with Dawson and Tricarico (1999) and Krueger and Adesogan (2008), who noted that enzyme mixtures containing cellulase were more inclined to alter the relative proportions of SCFA thereby resulting in more acetate and less propionate and less butyrate.

Feeding the enzyme preparation may have stimulated and/or increased total viable rumen bacterial numbers because rumen microbial $\mathrm{N}$ synthesis was increased which may be due, at least in part, to increased fiber digestion and an improved capacity of rumen bacteria to digest feed. Although this possibility may not be supported by Nsereko et al. (2002) and Krueger et al. (2007) who showed that while cellobiose and glucose utilizing bacteria were stimulated, effects on the fibrolytic population were negligible. Our results indicate that enzyme supplementation increased the quantity of microbial protein available to animal metabolism, and that increased fiber digestibility increased the net energy density of the ZADO enzyme diet.

Increased ammonia $\mathrm{N}$ concentration in cows fed the enzyme supplemented diet supports its capability to enhance rumen protein degradation, probably because it contained protease enzymes. However increased protein degradation may also reflect the more neutral rumen $\mathrm{pH}$ with enzyme addition, thereby increasing ruminal bacterial colonization of feed particles (Yang et al., 1999; Morgavi et al., 2000; Nsereko et al., 2000). However, Colombatto et al. (2007), working with an enzyme product rich in xylanolytic activity, concluded that exogenous enzymes had higher activity close to $\mathrm{pH}$ neutrality and that the hypothesis that exogenous enzymes have an effect on digestion when $\mathrm{pH}$ values were not optimal for fiber degradation is not supported.

\subsection{Milk production and composition}

A major finding of our study was that milk production was higher in enzyme supplemented cows ( 12.75 versus $15.70 \mathrm{~kg} / \mathrm{d}$ ). The enzyme diet was provided immediately after calving and a higher milk yield and DM intake was observed immediately. The large increase in DM intake, digestibility and ruminal fermentation activities suggest that increased milk production was due to feeding enzymes. Soliman (2006) reported 23\% higher milk production of dairy cows fed peanut hay ensiled with enzymes for $45 \mathrm{~d}$, and explained the improvement as being due to increased nutrient digestibility and microbial protein synthesis.

Studies on enzyme supplementation to dairy cow diets have shown increased milk yields of 7-15\% (Beauchemin et al., 1999; Lewis et al., 1999; Rode et al., 1999; Schingoethe et al., 1999; Yang et al., 2000), probably due to increased digestibility (Rode et al., 1999; Yang et al., 1999; Tricarico et al., 2005), as well as alteration of acetic/propionic acid ratio in the rumen (Rode et al., 1999; Giraldo 
et al., 2008), which increased energy available for milk production (Lewis et al., 1999; Yang et al., 1999).

\section{Conclusions}

The exogenous enzyme product $\left(\mathrm{ZADO}^{\circledR}\right)$, sourced from anaerobic bacterium and added to the TMR of cows in early lactation, increased milk production due to enhanced nutrient intake, and nutrient digestibility, as well as increased rumen microbial protein synthesis.

\section{References}

Adesogan, A.T., 2005. Improving forage quality and animal performance with fibrolytic enzymes. In: Florida Rum. Nutr. Symp., pp. 91-109.

Association of Official Analytical Chemists, 2000. In: Horwitz, W. (Ed.), Official Methods of Analysis of AOAC International, vol. 1, 17th ed. AOAC International, Gaithersburg, MD, USA, p. 26 (Chapter 4).

Association of Official Analytical Chemists, 1990. Official Methods of Analysis, 15th ed. AOAC, Arlington, VA, USA.

Beauchemin, K.A., Rode, L.M., 1996. Use of feed enzymes in ruminant nutrition. In: Rode, L.M. (Ed.), Proc. Can. Soc. Anim. Sci. Lethbridge, $A B$, Canada, pp. 103-130.

Beauchemin, K.A., Rode, L.M., Sewaltm, V.J.H., 1995. Fibrolytic enzymes increase fiber digestibility and growth rate of steers fed dry forages. Can. J. Anim. Sci. 75, 641-644.

Beauchemin, K.A., Morgavi, D.P., McAllister, T.A., Yang, W.Z., Rode, L.M., 2001. The use of enzymes in ruminant diets. In: Garnsworthy, P.C., Wiseman, J. (Eds.), Recent Advances in Animal Nutrition. Nottingham University Press, Loughborough, England, pp. 297-322.

Beauchemin, K.A., Yang, W.Z., Morgavi, D.P., Ghorbani, G.R., Kautz, W., Leedle, J.A.Z., 2003. Effects of bacterial direct-fed microbials and yeast on site and extent of digestion, blood chemistry, and subclinical ruminal acidosis in feedlot cattle. J. Anim. Sci. 81, 1628-1640.

Beauchemin, K.A., Yang, W.Z., Rode, L.M., 1999. Effect of grain source and enzyme additive on site and extent of nutrient digestion in dairy cows. J. Dairy Sci. 82, 378-390.

Bowman, G.R., Beauchemin, K.A., Shelford, J.A., 2002. The proportion of the diet to which fibrolytic enzymes are added affects nutrient digestion by lactating dairy cows. J. Dairy Sci. 85, 3420-3429.

Chen, X.B., Kyle, D.J., Ørskov, E.R., 1993. Measurement of allantoin in urine and plasma by high-performance liquid chromatography with pre-column derivation. J. Chromatogr. 617, 241-247.

Chen, X.B., Mathieson, J., Hovell, F.D., De, B., Reeds, P.J., 1990. Measurement of purine derivatives in urine of ruminants using automated methods. J. Sci. Food Agric. 53, 23-33.

Colombatto, D., Mould, F.L., Bath, M.K., Morgavi, D.P., Beauchemin, K.A., Owen, E., 2003. Influence of fibrolytic enzymes on the hydrolysis and fermentation of pure cellulose and xylan by mixed ruminal microorganisms in vitro. J. Anim. Sci. 81, 1040-1050.

Colombatto, D., Mould, F.L., Bhat, M.K., Owen, E., 2007. Influence of exogenous fibrolytic enzyme level and incubation pH on the in vitro ruminal fermentation of alfalfa stems. Anim. Feed Sci. Technol. 137, 150-162.

Davidson, J., Mathieson, J., Boyne, A.W., 1970. The use of automation in determining nitrogen by the Kjeldahl method with final calculation by computer. Analyst 96, 181-193.

Dawson, K.A., Tricarico, J.M., 1999. The use of exogenous fibrolytic enzymes to enhance microbial activities in the rumen and performance of ruminant animals. In: Proc. 15th Annual Symp. Biotech. Feed Industry, Loughborough, Leics, UK, pp. 303-312.

DeFrain, J.M., Hippen, A.R., Kalscheur, K.F., Tricarico, J.M., 2005. Feeding alpha-amylase improves the glycemic status and performance of transition dairy cows. J. Dairy Sci. 88, 4405-4413.

El-Adawy, M.M., Salem, A.Z.M., Borhami, B.E., Gado, H.M., Khalil, M.S., Abo-Zeid, A., 2008. In vitro cecal gas production and dry matter degradability of some browse leaves in presence of enzymes from anaerobic bacterium in NZW rabbit. In: The 9th WRSA World Rabbit Congress, Verona, Italy, June 10-13, pp. 643-647.

Eun, J.-S., Beauchemin, K.A., Schulze, H., 2007. Use of an in vitro fermentation bioassay to evaluate improvements in degradation of alfalfa hay. Anim. Feed Sci. Technol. 35, 315-328.

Feng, P., Hunt, C.W., Pritchard, G.T., Julien, W.E., 1996. Effect of enzyme preparations on in situ and in vitro degradation and in vivo digestive characteristics of mature cool-season grass forage in beef steers. J. Anim. Sci. 74, 1349-1357.

Firkins, J.L., Allen, M.S., Oldick, B.S., Pierre, N.R., 1998. Modeling ruminal digestibility of carbohydrates and microbial protein flow to the duodenum. J. Dairy Sci. 81, 3350-3369.

Gado, H., 1997. Effect of enzymatic treatments for poor quality roughages on fiber digestibility and nitrogen metabolism in Baladi goats. Egyptian J. Nutr. Feeds, 50-56 (special issue).

Gado, H.M., Metwally, H.M., Soliman, H., Basiony, A.Z.L., El Galil, E.R., 2007. Enzymatic treatments of bagasse by different sources of cellulase enzymes. In: The 11th Conf. Animal Nutr., Al-Aqsor-Aswan, Egypt on 2 November, 13-18, vol. 10 , p. 607.

Gado, H.M., Salem, A.Z.M., 2008. Influence of exogenous enzymes from anaerobic source on growth performance, digestibility, ruminal fermentation and blood metabolites in lambs fed of orange pulp silage in total mixed ration. In: 59th Annual Meeting of the European Association for Animal Production, Vilnius, Lithuania, August 24-27, p. 228 (Abstract).

Giraldo, L.A., Ranilla, M.J., Tejido, M.L., Carro, M.D., 2004. Effect of enzyme application method on in vitro rumen fermentation of tropical forages. J. Anim. Feed Sci. 13, 63-66.

Giraldo, L.A., Tejido, M.L., Ranilla, M.J., Carro, M.D., 2008. Effects of exogenous fibrolytic enzymes on in vitro ruminal fermentation of substrates with different forage:concentrate ratios. Anim. Feed Sci. Technol. 141, 306-325. 
Hristov, A.N., Basel, C.E., Melgar, A., Foley, A.E., Ropp, J.K., Hunt, C.W., Tricarico, J.M., 2008. Effect of exogenous polysaccharidedegrading enzyme preparations on ruminal fermentation and digestibility of nutrients in dairy cows. Anim. Feed Sci. Technol. $145,182-193$.

Hristov, A.N., McAllister, T.A., Cheng, K.-J., 2000. Intraruminal supplementation with increasing ruminal levels of polysaccharidedegrading enzymes: effect on nutrient digestion in cattle fed a barley grain diet. J. Anim. Sci. 78, 477-487.

Hristov, A.N., Rode, L.M., Beauchemin, K.A., Wuerfel, R.L., 1996. Effect of a commercial enzyme preparation on barley silage in vitro and in sacco dry matter degradability. Proc. West. Sect. Am. Soc. Anim. Sci. 47, 282-284.

Kim, S.W., Standford, D.G., Roman-Rosario, H., Yokoyama, M.T., Rust, S.R., 2000. Potential use of Propionibacterium acidipropionici, strain DH42, as a direct-fed microbial for cattle. J. Anim. Sci. 78 (Suppl. 1), 1225 (Abstract).

Krause, M., Beauchemin, K.A., Rode, L.M., Farr, B.I., Nørgaard, P., 1998. Fibrolytic enzyme treatment of barley grain and source of forage in high-grain diets fed to growing cattle. J. Anim. Sci. 76, 2912-2920.

Krueger, N.A., Adesogan, A.T., 2008. Effects of different mixtures of fibrolytic enzymes on digestion and fermentation of bahiagrass hay. Anim. Feed Sci. Technol. 145, 84-94.

Krueger, N.A., Adesogan, A.T., Staples, C.R., Littell, R.C., Dean, D.B., Krueger, W.K., 2007. The potential to increase the digestibility of tropical grasses with a fungal ferulic acid esterase enzyme preparation. Anim. Feed Sci. Technol. 145, 95108.

Krueger, N.A., Adesogan, A.T., Staples, C.R., Krueger, W.K., Kim, S.C., Littell, R.C., Sollenberger, L.E., 2008. Effect of method of applying fibrolytic enzymes or ammonia to Bermuda grass hay on feed intake, digestion, and growth of beef steers. J. Anim. Sci. 86, 882-889.

Kung, L., Treacher, R.J., Nauman, G.A., Smagala, A.M., Endres, K.M., Cohen, M.A., 2000. The effect of treating forages with fibrolytic enzymes on its nutritive value and lactation performance of dairy cows. J. Dairy Sci. 83, 115-122.

Lewis, G.E., Hunt, C.W., Sanchez, W.K., Treacher, R., Pritchard, G.T., Feng, P., 1996. Effect of direct-fed fibrolytic enzymes on the digestive characteristics of a forage-based diet fed to beef steers. J. Anim. Sci. 74, 3020-3028.

Lewis, G.E., Sanchez, W.K., Hunt, C.W., Guy, M.A., Pritchard, G.T., Swanson, B.I., Treacher, R.J., 1999. Effect of direct-fed fibrolytic enzymes on the lactational performance of dairy cows. J. Dairy Sci. 82, 611-617.

Lewis, G.E., Sanchez, W.K., Treacher, R.C., Hunt, W., Pritchard, G.T., 1995. Effect of direct-fed fibrolytic enzymes on lactational performance of midlactation Holstein cows. Proc. West. Sect. Am. Soc. Anim. Sci. Can. Soc. Anim. Sci. 46, 310-313.

McAllister, T.A., Hristov, A.N., Beauchemin, K.A., Rode, L.M., Cheng, K.-J., 2001. Enzymes in ruminant diets. In: Bedford, M., Partridge, G. (Eds.), Enzymes in Farm Animal Nutrition. CABI Publishing, Oxon, UK, pp. 273-298.

Morgavi, D.P., Beauchemin, K.A., Nsereko, V.L., Rode, L.M., McAllister, M., Wang, Y., 2000. A trichoderma feed enzyme preparation enhances adhesion of fibrobacter succinogenes to complex substrates but not to pure cellulose. In: 25th Conf. Rumen Function, Chicago, IL, USA, p. 33.

National Research Council (NRC), 2001. Nutrient Requirements of Dairy Cattle, 7th ed. National Academy.

Nsereko, V.L., Beauchemin, K.A., Morgavi, D.P., Rode, L.M., Furtado, A.F., McAllister, T.A., Iwaasa, A.D., Yang, W.Z., Wang, Y., 2002. Effect of a fibrolytic enzyme preparation from Trichoderma longibrachiatum on the rumen microbial population of dairy cows. Can. J. Microbiol. 48, 14-20.

Nsereko, V.L., Morgavi, D.P., Rode, L.M., Beauchemin, K.A., McAllister, T.A., 2000. Effects of fungal enzyme preparations on hydrolysis and subsequent degradation of alfalfa hay fiber by mixed rumen microorganisms in vitro. Anim. Feed Sci. Technol. $88,153-170$.

Ranilla, M.J., Tejido, M.L., Giraldo, L.A., Tricárico, J.M., Carro, M.D., 2008. Effects of an exogenous fibrolytic enzyme preparation on in vitro ruminal fermentation of three forages and their isolated cell walls. Anim. Feed Sci. Technol. 145, 109-121.

Rhine, E.D., Sims, G.K., Mulvaney, R.L., Pratt, E.J., 1998. Improving the Bertholot reaction for determining ammonium in soil extracts and water. Soil Sci. Soc. Am. J. 62, 473-480.

Rode, L.M., Yang, W.Z., Beauchemin, K.A., 1999. Fibrolytic enzyme supplements for dairy cows in early lactation. J. Dairy Sci. 82, 2121.

Rodrigues, M.A.M., Pinto, P., Bezerra, R.M.F., Dias, A.A., Guedes, C.V.M., Cardoso, V.M.G., Cone, J.W., Ferreira, L.M.M., Colaço, J., Sequeira, C.A., 2008. Effect of enzyme extracts isolated from white-rot fungi on chemical composition and in vitro digestibility of wheat straw. Anim. Feed Sci. Technol. 141, 326-338.

Salem, A.Z.M., El-Adawy, M.M., Gado, H., Khalil, M.S.M., 2007. Feed intake, nutrient digestibility and animal growth performance in sheep and goats fed wheat straw. ADSA PSA AMPA ASAS Joint Annual Meeting, San Antonio, TX, USA, July 8-12. J. Anim. Sci. 85 (Suppl. 1), 107 (Abstract).

SAS, 2001. Users Guide: Statistics (Release 8.01). SAS Inst. Inc., Cary, NC, USA.

Schingoethe, D.J., Stegeman, G.A., Treacher, R.J., 1999. Response of lactating dairy cows to a cellulase and xylanase enzyme mixture applied to forages at the time of feeding. J. Dairy Sci. 82, 996-1003.

Soliman, M.S., 2006. Utilization of peanut hay in ruminant feeding. Ph.D. Thesis. Alexandria University, Alexandria, Egypt.

Stella, A.V., Paratte, R., Valnegri, L., Cigalino, G., Soncini, G., Chevaux, E., Dell'Orto, V., Savoini, G., 2007. Effect of administration of live Saccharomyces cerevisiae on milk production, milk composition, blood metabolites, and faecal flora in early lactating dairy goats. Small Rumin. Res. 67, 7-13.

Stewart, C.S., Flint, H.J., Byrant, M.P., 1997. The rumen bacteria. In: Hobson, P.N., Stewart, C.S. (Eds.), The Rumen Microbial Ecosystem, 2nd ed. Blackie Academic and Professional, New York. NY, USA, pp. 10-55.

Steel, R.G.D., Torrie, J.H., 1980. Principles and Procedures of Statistics, 2nd ed. McGraw-Hill International, New York, NY, USA.

Titi, H., Lubbadeh, W.F., 2004. Effect of feeding cellulase enzyme on productive responses of pregnant and lactating ewes and goats. Small Rumin. Res. 52, 137-143.

Tyrrell, H.F., Reid, J.T., 1965. Prediction of the energy value of cow's milk. J. Dairy Sci. 48, 1215-1223.

Tricarico, J.M., Johnston, J.D., Dawson, K.A., Hanson, K.C., McLeod, K.R., Harmon, D.L., 2005. The effects of an Aspergillus oryzae extract containing alpha-amylase activity on ruminal fermentation and milk production in lactating Holstein cows. Anim. Sci. 81, 365-374.

Van Soest, P.J., Robertson, J.B., Lewis, B.A., 1991. Methods for dietary fiber, neutral detergent fiber and non-starch polysaccharides in relation to animal nutrition. J. Dairy Sci. 74, 3583-3597.

Varga, G.A., Dann, H.M., Ishler, V.A., 1998. The use of fiber concentrations for ration formulation. J. Dairy Sci. 81, 3063-3074. 
Wallace, R.J., Wallace, S.J.A., McKain, N., Nsereko, V.L., Hartnell, G.F., 2001. Influence of supplementary fibrolytic enzymes on the fermentation of corn and grass silages by mixed ruminal microorganisms in vitro. J. Anim. Sci. 79, 1905-1916.

Wang, Y., McAllister, T.A., Rode, L.M., Beauchemin, K.A., Morgavi, D.P., Nsereko, V.L., Iwaasa, A.D., Yang, W., 2001. Effects of an exogenous enzyme preparation on microbial protein synthesis, enzyme activity and attachment to feed in the Rumen simulation technique (Rusitec). Br. J. Nutr. 85, 325-332.

Wang, Y., Spratling, B.M., ZoBell, D.R., Wiedmeier, R.D., McAllister, T.A., 2004. Effect of alkali pretreatment of wheat straw on the efficacy of exogenous fibrolytic enzymes. J. Anim. Sci. 82, 198-208.

Yang, W.Z., Beauchemin, K.A., Rode, L.M., 1999. Effects of an enzyme feed additive on extent of digestion and milk production of lactating dairy cows. J. Dairy Sci. 82, 391-403.

Yang, W.Z., Beauchemin, K.A., Rode, L.M., 2000. A comparison of methods of adding fibrolytic enzymes to lactating cow diets. J. Dairy Sci. 83, 2512-2520. 